Foreign Direct Investment and Regional Trade Agreements: The Market Size Effect Revisited

Florence Jaumotte 
IMF Working Paper

Middle East and Central Asia Department

\title{
Foreign Direct Investment and Regional Trade Agreements: The Market Size Effect Revisited
}

\author{
Prepared by Florence Jaumotte ${ }^{1}$ \\ Authorized for distribution by Erik De Vrijer
}

November 2004

\begin{abstract}
This Working Paper should not be reported as representing the views of the IMF. The views expressed in this Working Paper are those of the author(s) and do not necessarily represent those of the IMF or IMF policy. Working Papers describe research in progress by the author(s) and are published to elicit comments and to further debate.

The paper investigates whether the market size of a regional trade agreement (RTA) is a determinant of foreign direct investment (FDI) received by countries participating in the RTA. This hypothesis is tested on a sample of 71 developing countries during the period 1980-99. Evidence is found that the RTA market size had a positive impact on the FDI received by member countries, even more so in the 1990s when such agreements were revived and became more widespread. The size of domestic population also seemed to matter, possibly because of its effect on the availability of the labor supply. It appears, however, that not all countries in the RTA benefited to the same extent from the RTA: countries with a relatively more educated labor force and/or a relatively more stable financial situation tended to attract a larger share of FDI at the expense of their RTA partners. This evidence suggests it is essential for all RTA countries to improve their business environment to the best available in the region. Finally, a partial negative correlation between the FDI received by RTA countries and that received by non-RTA countries possibly reflects a diversion of FDI from non-RTA to RTA countries. As an illustration, FDI benefits are simulated from the creation of a regional trade agreement between Algeria, Morocco, and Tunisia.
\end{abstract}

JEL Classification Numbers: F13, F15, F21

Keywords: Foreign direct investment; Regional trade agreements; Economic integration; Market size; Scale economies

Author(s) E-Mail Address: Florence.JAUMOTTE@,oecd.org

\footnotetext{
1 This paper was prepared while working as an economist in the IMF's Middle Eastern Department. I am grateful to Michel Lazare, Edward Gardner, and Patrizia Tumbarello for their help in shaping this project. Thanks also go to Peter Allum, Robert Barro, David Burton, Philippe Callier, S. Nuri Erbas, Domenico Fanizza, Mangal Goswami, Hervé Joly, Edouard Martin, and Randa Sab for their helpful comments. All remaining errors are mine.
} 


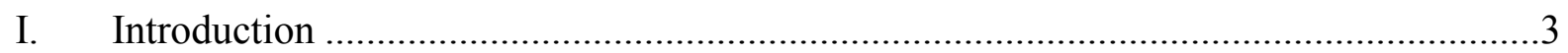

II. RTA and FDI: A First Look at the Data...............................................................

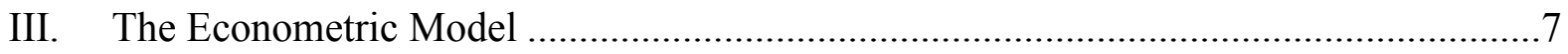

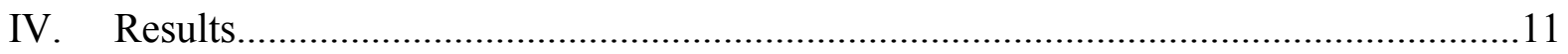

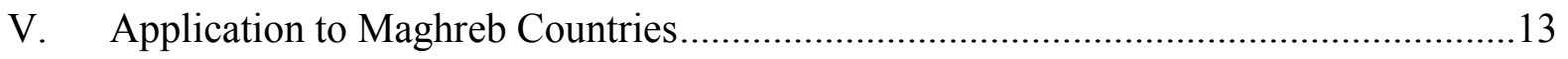

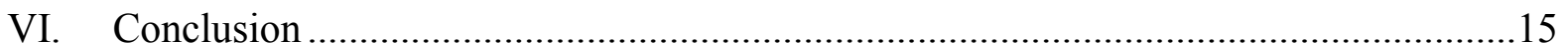

Tables

1. Ratio of Average Stock of FDI to GDP — Comparison RTA Versus Non-RTA ...........17

2. Ratio of Average FDI Inflow to GDP ...................................................................... 17

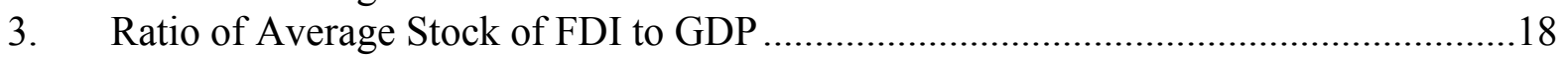

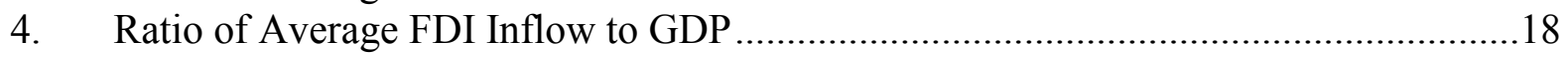

5. Autoregressive Model of the Level of FDI Stock ...................................................19

6. Regional Model: Estimation in First Difference and Instrumentation.........................20

7. Regional Model: Sensitivity Tests ..........................................................................21

8. FDI in Percent of GDP for Maghreb Countries .......................................................22

9. Actual and Predicted FDI Stock-to-GDP Ratio for Maghreb Countries .....................23

10. Actual and Predicted Average Annual Growth of the FDI Stock-to-GDP Ratio ..........24

11. Growth in the FDI Stock-to-GDP Ratio Implied by the Creation of a Maghreb Regional Market...................................................................................................24

Figures

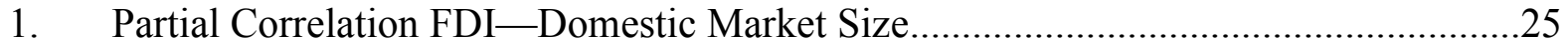

2. Partial Correlation FDI-Regional Market Size .................................................25

Appendices

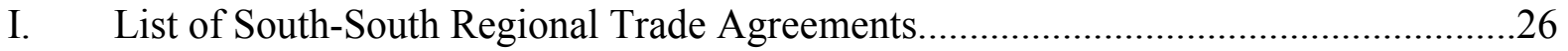

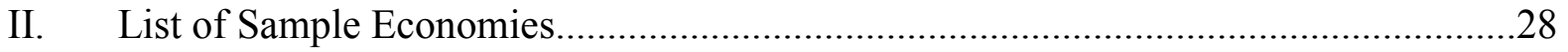

III. Summary Statistics and Correlation Matrix ......................................................29

Appendix Tables

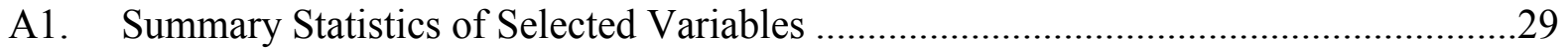

A2. Correlation Matrix Between Selected Variables.........................................................29

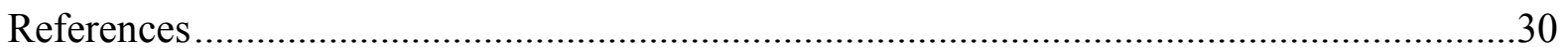




\section{INTRODUCTION}

The 1990s witnessed a spread of regional trade agreements (RTAs), including many between developing countries. Among the newly created RTAs are Mercosur, the Group of Three, and the Cross-Border Initiative. Existing RTAs have also been revived and have increased their membership. Many developing countries are in an RTA or are discussing the possibility. Although they are not always without costs, ${ }^{2}$ RTAs provide the benefits of free trade within the confines of a regional group. These include the exploitation of comparative advantage with partner countries, increased competition leading to greater efficiency, and a larger market allowing the exploitation of economies of scale. These efficiency gains can turn into dynamic gains by increasing growth, as well as domestic and foreign investment. In many instances, foreign direct investment (FDI) may actually act as an essential catalyst for these dynamic benefits to materialize. FDI is valued for the activity and employment it creates, the incentives it gives to domestic producers to increase their efficiency, and the technology and know-how transfers it may generate. ${ }^{3}$ As such, the effect of RTAs on FDI is the central focus of this paper.

RTAs may affect the incentives for FDI through multiple channels (Blomström and Kokko, 1997). The implementation of an RTA usually involves the reduction/elimination of tariff and non-tariff barriers between RTA members, and the imposition of a common external tariff vis-à-vis non-members. The theory predicts a positive impact of such measures on an interregional FDI, but an ambiguous effect on intraregional FDI, which depends on the structure and motives for pre-existing investment. ${ }^{4}$ The positive effect on FDI inflows from outsiders is likely to arise from the larger market size. Indeed, FDI involves a non-negligible set-up cost which generates increasing returns to scale and makes larger markets a more profitable investment opportunity than smaller markets. Firms whose competitiveness lies in intangible assets developed through research and development (R\&D) face even stronger increasing returns to scale, due to the large initial R\&D expenditures they incur. The market size effect applies mostly to market-seeking FDI, although vertical FDI (driven by a cost reduction motive) may also be stimulated if the output is destined for other members of the

\footnotetext{
${ }^{2}$ RTAs are considered of second-best nature compared to multilateral free trade because of the risk of trade diversion. Trade diversion occurs when import supply from countries outside the region is replaced by less efficient production from countries within the region. RTAs could even be worse than the status quo if trade diversion exceeded trade creation and other benefits of RTAs. However, this risk is reduced when the objective of the RTA is to promote exports and prepare the terrain for more effective competition outside the region instead of protecting import-substitution. RTAs have moved toward a more open kind of regionalism in the 1990s. For a discussion of the benefits and costs of RTAs, see for example De la Torre and Kelly (1992), and Baldwin and Venables (1995).

${ }^{3}$ See for example Blomström, Globerman, and Kokko (2000), Borenzstein, De Gregorio, and Lee (1995).

${ }^{4}$ In the case examined by this paper (RTAs between developing countries), FDI inflows from outsiders are likely to account for the major part of FDI, since developing countries carry little outward FDI themselves. This makes it more likely that the creation of an RTA will increase the overall level of FDI into the region.
} 
RTA. Interregional FDI may also increase if the average level of external protection increases or is expected to increase as a result of the RTA. ${ }^{5}$ Regarding intra-regional FDI, the lowering of internal tariffs tends to reduce the incentives for tariff-jumping FDI, but on the other hand facilitates vertical FDI which delocalizes the production process to the countries with the best advantage by location. Intra-regional FDI motivated by the exploitation of intangible assets should not be negatively affected by the lowering of internal tariffs. Finally, the significant efficiency benefits brought about by an RTA may feed into higher growth rates and possibly more $\mathrm{R} \& \mathrm{D}$, which would further stimulate both interregional and intraregional FDI.

However, even if an RTA increases the overall level of FDI, the surge in FDI is unlikely to be evenly distributed among the members. On the contrary, it is likely to be geographically concentrated in the RTA members with the strongest advantage by location. Existing production facilities may also be reorganized and concentrated in these same countries, implying a loss of existing FDI for countries with less locational advantages. Such a phenomenon is more likely to occur in sectors for which economies of scale are large relative to transport costs, such as more technology-intensive sectors.

Most of the empirical evidence on the FDI effects of RTAs is from the European Internal Market Programme (IMP). In a survey of the literature, Dunning (1997) concludes that the IMP had positive effects on both interregional and intraregional FDI in the European Community (EC), but more so on interregional than intraregional FDI. Although this variable was not as significant as the other determinants of FDI, Dunning questions whether the IMP can really be considered as an independent variable, since its main effects will be through market size, income levels, the structure of economic activity, and agglomeration economies. Pain and Landsbury (1996) find an increase of intra-regional FDI by the United Kingdom and Germany as the IMP was implemented during 1980-92. They also find little support for the proposition that IMP led to a more pronounced intra-EC concentration of economic activity, though some countries lost FDI (e.g., France and Belgium). However, they find some evidence of investment diversion from the United States and Austria to the benefit of the EC (in the case of German outward FDI). Girma (2001) adopts a different methodological approach to test the effect of the IMP on inward FDI in the U.K. manufacturing sector. Instead of a simple intercept shift (captured by a dummy variable for the IMP), he interacts the IMP dummy with the determinants of FDI, and includes both the European market size and the domestic size as potential determinants of FDI. He concludes that the size of the European market and the unit labor costs relative to the rest of the EC became more important determinants of FDI than local market size as the IMP was implemented. ${ }^{6}$

\footnotetext{
${ }^{5}$ Such fears are believed to have been behind the surge in Japanese FDI into the European Single Market.

${ }^{6}$ This finding applies mostly to FDI for acquisitions, and less so to FDI for start-ups, for which the size of the U.K. market remains as important as before.
} 
Another RTA which has attracted a lot of attention is Mercosur, created in 1991 and consisting of Argentina, Brazil, Paraguay, and Uruguay. The creation of Mercosur resulted in strong increases in inflows of FDI into the region, and more particularly into Argentina and Brazil. Blomström and Kokko (1997) argue that the achievement of macroeconomic stability appeared to be a pre-condition for the FDI response to materialize in Argentina and later in Brazil. Moreover, Brazil and Argentina had large privatization programs that could probably have been one factor leading to the FDI increase (Chudnovsky, Lopez, and Porta, 1995). Finally, the inflows of FDI into the region were not distributed equally between participating countries, with mixed experiences for Uruguay and Paraguay. However, the main gains from the RTA for these countries are likely to be dynamic, with higher growth and increased demand for their exports in the entire Mercosur region.

This paper focuses on the experience of developing countries with RTAs, and more particularly tests the effect of enlarged market size on the newly received FDI as well as the importance of locational advantages within the RTA. For this purpose, the focus is essentially on South-South RTAs, or RTAs which involve only developing countries. NorthSouth RTAs, which involve industrial and developing countries, are not taken into account, because the increase in FDI received by the southern countries in such cases results mostly from a cost reduction motive by the northern country and is less related to the enlargement of the market size to which the southern country gives access. The sample covers 71 developing countries over the period 1980-99. The results show a significantly positive effect of RTA market size on FDI. The size of domestic population also matters, probably due to its effect on the availability of labor supply. However, the regressions confirm the importance of relative locational advantages within the RTA, in particular as far as education and financial stability are concerned: the higher the educational level and financial stability relative to other members of the RTA, the larger the FDI received by the country. Finally, the paper finds evidence of a negative partial correlation between the FDI received by RTA countries and that received by non-RTA countries, possibly reflecting diversion effects. A simulation of the potential FDI benefits from the creation of a RTA between Algeria, Morocco, and Tunisia illustrates the necessity for each RTA member to improve the domestic business and investment environment to the best available in the region in order to share in the FDI benefits.

Section II analyzes the distribution of FDI between RTA and stand-alone countries, and looks at its evolution over time. Section III discusses the determinants of FDI and the econometric specifications used to test for the presence of a regional market size effect. The results of the estimations are presented in Section IV. Section V attempts to estimate the FDI gains that could result from the creation of an RTA between Algeria, Morocco, and Tunisia. Finally, Section VI concludes the paper.

\section{RTA AND FDI: A FIRST LOOK AT THE DATA}

Data on FDI flows and stocks are taken from the World Investment Report (UNCTAD, 2000). In this report FDI is defined as an "investment involving a long-term relationship and 
reflecting a lasting interest and control of a resident entity in one economy in an enterprise resident in an economy other than that of the foreign direct investor." FDI flows comprise three components, namely equity capital, reinvested earnings and intra-company loans transactions. For most countries, these data are originally from the IMF Balance of Payments Statistics Yearbook. FDI stocks are at book value or historical cost, reflecting prices at the time when the investment was made. For many countries, FDI stocks were calculated by accumulating FDI flows over a period of time or adding FDI flows to some benchmark estimate of the FDI stock. The sample was split into five-year periods (1980-85, 1985-90, 1990-95, and 1995-99). Beginning-of-period FDI stocks and annual average FDI inflows over each sub-period were converted into 1995 U.S. dollars. ${ }^{7}$

Table 1 compares the average stock of FDI in percent of GDP for RTA and non-RTA countries. $^{8}$ In the $1980 \mathrm{~s}$, RTA countries had somewhat smaller stocks of FDI than non-RTA countries. However, since 1990, their stocks of FDI have outgrown substantially those of non-RTA countries by 33 percent on average. The average stock of FDI for RTA countries was 24 percent of GDP in the 1990s versus 18 percent for non-RTA countries. During the 1980s and 1990s combined, RTAs' stocks of FDI were on average 3 percentage point larger than non-RTAs' stocks.

Table 2 reports average FDI inflows in percent of GDP for RTA and non-RTA countries. ${ }^{9}$ Although the differences between RTA and non-RTA countries are less marked, the data point to larger FDI inflows into RTA countries at the end of the period (1995-99). Thus, the prima facie evidence seems to indicate a positive effect of RTAs on FDI, at least in the 1990s. However, a careful examination of the question will require using an econometric model of FDI that isolates the effect of regional market size and controls for other determinants of FDI.

Tables 3 and 4 compare FDI received by RTA countries in different geographical areas. The ASEAN countries received the most FDI, with an average FDI stock of 44 percent of GDP in 1999. Their net FDI inflows averaged 4.5 percent of GDP over the 1980s and 1990s. The second most attractive RTA countries are from the Western Hemisphere with an average FDI stock of 39 percent of GDP in 1999. Their net FDI inflows averaged 2.1 percent of GDP over the 1980s and 1990s, and as much as 4.8 percent over the period 1995-99. Finally come the

\footnotetext{
${ }^{7}$ The 1980 FDI stock was deflated using the average GDP deflator for 1976-80. FDI flows for each subsequent five-year period were expressed in 1995 U.S. dollars, using the average GDP deflator for the corresponding sub-period.

${ }^{8}$ A list of South-South RTAs and their composition is given in Appendix I.

${ }^{9}$ For each country, the stock of FDI in percent of GDP (FDI/Y) and the net FDI inflows in percent of GDP $(\mathrm{I} / \mathrm{Y})$ are related in the following way: $\frac{F D I_{t}}{Y_{t}}=\left(\frac{F D I_{t-1}}{Y_{t-1}}+\frac{I_{t}}{Y_{t-1}}\right) \cdot \frac{Y_{t-1}}{Y_{t}}$.
} 
Gulf Cooperation Council (GCC) and sub-Saharan RTA countries with an average FDI stock of 25 percent of GDP in 1999. This is equal to the average for all non-RTA countries in 1999 (see Table 1). Over the period 1980-99, the net FDI inflows averaged 1.7 percent of GDP for the GCC, and 1.3 percent of GDP for sub-Saharan RTA countries. In the 1990s, net FDI inflows in GCC countries averaged 2.5 percent of GDP, while those in sub-Saharan RTA countries averaged 1.5 percent of GDP.

\section{THE ECONOMETRIC MODEL}

The model attempts to explain the stock of FDI received by a country (expressed in 1995 U.S. dollars). To the extent that FDI may be reversible, the stock of FDI provides a better measure of the actual "inflow of FDI" than does the increment in the FDI stock. The main determinants considered in this model follow other studies ${ }^{10}$ and include the following factors.

\section{Size of the host market}

Most studies find a highly significant and positive effect of domestic market size and its expected growth on the FDI received by a country. ${ }^{11}$ The model therefore includes domestic market size, proxied by real GDP, and its expected growth, proxied by past real GDP growth. However, in order to test for a regional market size effect, this model introduces an alternative measure of market size which takes the value of the regional market size for countries belonging to a RTA and the value of domestic market size for stand-alone countries. The regional market size is calculated as the sum of the domestic market size and of the market size of all the countries sharing an RTA with the country considered. ${ }^{12}$ When a country belongs to multiple RTAs, the measure of regional market size includes the partner countries in all the RTAs of which the country is a member. This measure is imperfect as it does not take into account the extent of intra-RTA trade liberalization and hence the actual degree of integration of the markets of the RTA members. However, for practical purposes, it provides a useful benchmark measure of regional market size. Data on GDP are taken from the World Economic Outlook (IMF) and the World Development Indicators of the World Bank (2001), and converted into 1995 U.S. dollars.

\footnotetext{
${ }^{10}$ This section is based on the literature review of Lim (2001). More references can be found in this paper. Other reviews of the typical determinants of FDI can be found in Caves (1996), Singh and Jun (1995), and Michalet (1997).

${ }^{11}$ Studies include expected market growth because FDI is typically a long-run and therefore forward-looking decision.

${ }^{12}$ As mentioned before, the measure of regional market size is limited to countries which share a "South-South" regional trade agreement and ignores "North-South" regional trade agreements.
} 


\section{Agglomeration effects}

There may be incentives to locate new FDI close to existing FDI due to linkages between projects, availability of support services, or because the presence of other firms signals favorable national conditions for FDI. Several studies found that agglomeration effects are important in explaining FDI. The lagged value of the stock of FDI is one possible measure of the incentives for clustering and is therefore included in the model. However, this variable can also be interpreted as capturing the sluggishness in the adjustment of the stock of FDI to its optimal level in an error correction mechanism. ${ }^{13}$ Another agglomeration-related variable is the quality of infrastructure. Unfortunately, most traditional indicators for infrastructure development are not available for many developing countries over a long time period. The model therefore uses as a proxy the number of television sets per capita as reported in the World Development Indicators of the World Bank (2001).

\section{Labor cost and quality}

Part of the FDI in developing countries is motivated by cheap labor costs and a reduction of production costs. This so-called "vertical FDI" consists in removing to the developing country the labor-intensive stages of the production process in order to benefit from lower labor costs. For other types of FDI, quality labor is more important than cheap labor. For example, firms which produce differentiated goods and are in search of new markets need local staff that will be able to operate the production technology used in the source country. Accordingly, the empirical evidence on the effect of wage costs is somewhat mixed, depending on the type of FDI considered, while some evidence of a positive effect of education on FDI is found in several studies. Labor cost data for such a large sample of developing countries over such a long period would be difficult to collect. On the other hand, the model includes the average schooling years in the population over age 15 as a proxy for labor quality and, to some extent, as an inverse proxy for labor cost. The education data is from Barro and Lee (2000).

\section{Business/investment climate}

The business/investment climate influences the additional cost of doing business in a foreign country. The Political Risk Services Group has constructed several indices to measure the risk of doing business in a given country. First, the political risk index measures the internal and external political stability, the government's attitude toward inward investment, the level of corruption in the political system, the quality of the bureaucracy, and the degree of rule and law enforcement. Second, the financial risk index measures the current account and foreign debt position, the net liquidity, and exchange rate stability. Finally, the economic risk index is based on the budget position, the current account, inflation, real GDP growth and

\footnotetext{
13 Denote FDI by $x$ and the optimal level by *. If $x$ adjusts sluggishly to its optimal level $x^{*}$, i.e., $x-x_{-1}=y\left(x^{*}-x_{-1}\right)$ with $0<y<1$, it follows that $x=(1-y) x_{-1}+y x^{*}$.
} 
output per capita. Previous studies have found a negative impact of an unfavorable business climate on FDI, though the evidence on the regulatory, bureaucratic and judicial environment is less strong, perhaps due to measurement problems. All three risk indices are highly positively correlated, but when introduced simultaneously only the financial risk index remains significant. The financial risk index is therefore the measure used in the model.

\section{Openness}

The degree of a country's openness can affect FDI in multiple ways. Lower import barriers discourage tariff-jumping FDI but may stimulate vertical FDI by facilitating the imports of inputs and machinery. Lower export barriers tend to stimulate vertical FDI by facilitating the re-export of processed goods, and other (non-tariff-jumping) horizontal FDI by expanding the effective market size and leading to an improved business climate and expectations of better long-term economic growth. The evidence of openness is mixed, depending on the type of FDI considered, although on balance the evidence points to a positive effect of openness on FDI. Openness is commonly measured by the export-to-GDP ratio. However, following Barro and Sala-i-Martin (1999), this paper corrects the export-to-GDP ratio for the size of the country, as it is well known that country size has a negative effect on such measures of openness independently of the country's trade policy. ${ }^{14}$ The trade data are taken from the Direction of Trade Statistics (IMF, 2000).

\section{Other}

The model also includes time- and country-specific fixed effects: time effects control for trends in world FDI unrelated to the countries' fundamentals, while country effects capture country-specific determinants of FDI such as natural resource endowment and possibly specific tax regimes that stimulate particular types of FDI. Fiscal incentives as such are not included in the model due to data constraints and lack of evidence of a significant effect in the literature. Indeed, many studies found mixed results on the effect of fiscal incentives. Possible explanations include the potentially transient nature of such incentives, the possibility of deducting taxes paid in a foreign country from domestic taxes (at least in some countries), and the scope for tax avoidance through transfer pricing.

\section{The specifications}

The basic model, called "domestic model," relates the stock of FDI received by a country to its domestic market size as well as the other determinants of FDI described above, but does not include regional variables. It reads:

\footnotetext{
${ }^{14}$ The model only includes the export-to-GDP ratio because export- and import-to GDP ratios are highly correlated. The logarithm of the export-to-GDP ratio is regressed on a constant and the country's size, measured by the logarithms of population and area. The trade openness measure is the exponential of the residual (including the intercept term).
} 


$$
\begin{aligned}
& \ln \left(F D I_{i, t+1}\right)=\lambda \ln \left(F D I_{i, t}\right)+\alpha \ln \left(Y_{i, t}\right)+\beta\left(g_{Y i, t}\right)+\gamma \ln \left(\text { educ }_{i, t}\right)+\delta \ln \left(\operatorname{stabfin}_{i, t}\right)+\phi \ln \left(\text { tv }_{i, t}\right) \\
& +\operatorname{\theta res}(X / Y)_{i, t}+\mu_{i}+\omega_{t+1}+\varepsilon_{i, t+1},
\end{aligned}
$$

where FDI denotes the stock of FDI (in 1995 U.S. dollars), $Y$ denotes real GDP (in 1995 U.S. dollars), $g_{Y}$ denotes real GDP growth, educ denotes the average years of education of people over age 15, stabfin is the financial risk index of the Political Risk Services Group, $t v$ is the number of televisions per capita, $\operatorname{res}(X / Y)$ is the measure of trade openness, $\mu$ denotes the country's fixed effect, and $\omega$ the time effect. In order to minimize endogeneity problems and capture the possibly slow adjustment of the FDI stock, the model uses the lagged value of the explanatory variables. Real GDP growth refers to the growth between $t-1$ and $t$.

The "regional" model builds on the domestic model by adding RTA-related variables: the regional market size; the average real growth rate in partner countries; and the gap between the domestic and RTA education level, financial stability, and infrastructure. The latter variables are aimed at measuring the locational advantage of country $i$ relative to other countries with which it shares a RTA. The higher the education level, the financial stability, and the infrastructure development in country $i$ compared to the countries with which it shares an RTA, the higher its locational advantage for FDI within the RTA. The effect of the average real growth rate in partner countries is more uncertain. On the one hand, a relatively high growth rate in partner countries implies that country $i$ may not be as dynamic and therefore as attractive as its partners. On the other hand, it implies that the regional market is expanding and may thus increase FDI of country $i$ on this account, particularly if country $i$ offers other locational advantages. In its most complete form, the model thus reads:

$$
\begin{aligned}
& \ln \left(F D I_{i, t+1}\right)=\lambda \ln \left(F D I_{i, t}\right)+\alpha_{1} \ln \left(Y_{i, t}\right)+\alpha_{2} \ln \left(R E G Y_{i, t}\right)+\beta_{1}\left(g_{Y i, t}\right)+\beta_{2}\left(R E G g_{Y i, t}\right) \\
& +\gamma_{1} \ln \left(e d u c_{i, t}\right)+\gamma_{2} \ln \left(\text { GAPeduc }_{i, t}\right)+\delta_{1} \ln \left(\operatorname{stabfin}_{i, t}\right)+\delta_{2} \ln \left(\text { APStabfin }_{i, t}\right)+\phi_{1} \ln \left(\text { tv }_{i, t}\right)+\phi_{2} \ln \left(\text { GAPtv }_{i, t}\right) \\
& +\operatorname{\theta res}(X / Y)_{i, t}+\mu_{i}+\omega_{t+1}+\varepsilon_{i, t+1},
\end{aligned}
$$

where the notations are as in equation (1), REGY denotes the market size extended to include RTA market size for countries belonging to a RTA, $R E G g_{y}$ denotes the average real growth rate in RTA partner countries (including country $i$ ), and the prefix GAP denotes the ratio between the domestic value of the variable and the average value for all countries sharing a RTA with country $i$ (including country $i$ itself). The measure of average education, financial stability, and infrastructure in the RTA partners is calculated for the maximum number of partners for which this data is available. However, in some cases, coverage was only available for a subset of the RTA countries. The implicit assumption made is that countries for which data is not available offer locational conditions similar to the average in the region. Although this assumption is probably too optimistic, it is the best that can be done given the current state of the data. 


\section{RESUlts}

The sample covers 71 developing countries during the period 1980-99. A list of the countries can be found in Appendix II. In order to focus on medium-term evolutions, the time interval considered is five years and the sample period is divided into four sub-periods, 1980-85, 1985-90, 1990-95, and 1995-99. The regressions thus relate the end-of-period FDI stock (e.g., 1985) to the beginning-of-period value of the determinants (e.g., 1980). About 65 percent of the observations are from countries that belong to a South-South RTA, while the other 35 percent are from countries that do not belong to an RTA. Appendix III presents summary statistics and correlations for the main variables used in the econometric analysis.

Table 5 reports the estimates of the domestic and regional models using feasible generalized least squares with correction for panel-heteroskedasticity. The results for the domestic model (column one) show a positive and statistically significant effect on FDI of lagged FDI, education, financial stability, and openness. The only control variable which is not significant is infrastructure; however the quality of the proxy used for infrastructure is debatable. Moreover, the lagged stock of FDI already controls to some extent for agglomeration effects and is itself very significant.

Focusing on market size, although the growth of domestic market size has a positive and significant effect on FDI, domestic market size itself is insignificant. In contrast, the estimations of the regional model (columns 2-3) show that the alternative measure of market size, which replaces domestic by regional market size for RTA countries, has a positive and significant effect on FDI. Figures 1 and 2 depict the partial correlations between FDI and respectively, domestic and regional market sizes. ${ }^{15}$ They show a zero or even negative correlation between FDI and domestic market size, but a robust positive correlation between FDI and regional market size.

The model in column 3 tests whether countries of a same RTA are in competition for the FDI received by the RTA through locational advantages such as a high education level, a high financial stability, a well-developed infrastructure, or a high rate of domestic market growth. Evidence is found of such a competition through education and financial stability. Indeed, the coefficients on the gaps between the domestic and RTA education level and financial stability are significantly positive, indicating that the RTA average education and financial stability exert a negative influence on the FDI received by the home country. The results for the infrastructure proxy are not significant in line with the results obtained for the domestic model. Finally, although domestic market growth has a positive effect on the FDI received, the regional average market growth has no significant impact. There are two counteracting effects at work here, as explained in Section III. A higher regional average market growth implies that other countries in the RTA are dynamic and therefore attractive for FDI. On the

\footnotetext{
${ }^{15}$ The partial correlation between a regressor and the dependent variable refers to the correlation between this regressor and the part of the dependent variable which is not explained by the other regressors. The calculation of the partial correlations is based on the competitive regional model reported in column 3 of Table 5.
} 
other hand, it also implies a higher growth of the regional market to which the home country gives access and may therefore increase FDI in the home country, particularly if it presents other locational advantages.

Table 6 reports estimates of the regional model in first difference. The main result is confirmed, namely that the alternative measure of market size (extended to include RTA market size) has a significantly positive effect on FDI. Most other variables, except the lagged stock of FDI, the education gap, and openness, lose significance in the first-difference estimation, possibly because of the smaller number of time periods (one time-period is lost due to first-differencing, yielding three instead of four time-periods). The estimation in column 2 uses instruments for the lagged dependent variable and the other potentially endogenous variables, namely the lagged first-differences of domestic market size and of domestic market growth. It is a well known fact that dynamic panel models can create a contemporaneous correlation between these regressors and the error term. ${ }^{16}$ Following the Arellano-Bond (1991) method, the model uses as instruments the second lag of the FDI stock, as well as the second lag of the first-differences of domestic market size, domestic market growth, domestic education, the education gap, domestic financial stability, the financial stability gap, domestic infrastructure, the infrastructure gap, and openness. The coefficient on RTA market size is robust to this correction and, despite the fact that the Arellano-Bond method tends to yield imprecise estimates, remains significant at the 10 percent level.

Table 7 presents some sensitivity tests of the relationship between RTAs and FDI. First, market size is split into GDP per capita and population. The component of RTA market size which matters is GDP per capita. Regarding domestic size, population actually seems to exert a positive effect on FDI. However, the latter may reflect more the effect of the availability of labor supply rather than market size. Within an RTA, FDI may prefer to locate in a country with a large labor supply.

The second sensitivity test interacts the domestic and RTA market size variables (measured by GDP) with dummies for the 1980s and the 1990s respectively. The estimation shows a more important role of the RTA market size variable in the 1990s than in the 1980s, possibly reflecting the revival of existing RTAs and creation of new RTAs during this period. To some extent, this test shows that if RTA market size could be more precisely measured by taking into account the effective degree of trade integration, the effect of this variable would most likely be even larger. On the other hand, the coefficient on the domestic market size variable changes from positive in the 1980s to negative in the 1990s, which seems consistent with the increased role of RTA market size. However, the two coefficients on domestic market size are imprecisely estimated so that not too much weight can be placed on this observation.

\footnotetext{
${ }^{16}$ Sevestre and Trognon (1996) discuss the potential for bias in the estimation of dynamic models with fixed effects.
} 
The last three regressions examine whether RTAs have attracted FDI at the expense of standalone countries. Diversion is measured by a variable which, for stand-alone countries, takes as value the average FDI received by RTA countries and, for RTA countries, takes as value the average FDI received by stand-alone countries. FDI is measured alternatively by the FDI inflow in percent of GDP (Measure 1), the end-of-period stock of FDI (Measure 2), and the beginning-of-period stock of FDI (Measure 3). The coefficients on these variables are negative and significant or close to significant in the case of the stock measures (Measures 2 and 3), pointing to a negative partial correlation between the FDI received by RTA countries and the FDI received by stand-alone countries.

\section{Application to Maghreb Countries}

As an illustration, this section analyzes the evolution of FDI in Maghreb countries and attempts to quantify the increase in FDI that could result from the creation of a regional market between Algeria, Morocco, and Tunisia.

\section{Evolution of FDI in Maghreb countries}

Table 8 reports the FDI stock-to GDP ratios and FDI inflow-to-GDP ratios for Algeria, Morocco, and Tunisia in the 1980s and 1990s. Tunisia appears to have attracted substantially more FDI relative to its size than Algeria and Morocco. It maintained an average stock of FDI close to 80 percent of GDP over the 1980s and 1990s. ${ }^{17}$ During this same period, the stock of FDI averaged 7 percent of GDP in Morocco and 4 percent of GDP in Algeria. Similarly, FDI inflows averaged 2.7 percent of GDP in Tunisia during the 1980s and 1990s, versus 1.1 percent in Morocco and about zero percent in Algeria.

In Algeria, the FDI stock-to-GDP ratio remained stagnant at 4 percent for most of the period, and decreased slightly to 3.5 percent in 1995-99. In contrast, Morocco started attracting much larger inflows of FDI in the 1990s, of the order of 2 percent of GDP. Consequently, its stock of FDI rose from 4 percent at the end of the 1980s to as much as 17 percent of GDP in 1999.

\section{Determinants of FDI in Maghreb countries}

The model appears to be a good predictor of the average level of the FDI stock-to-GDP ratio over the period 1980-99 for each of the countries. As reported in Table 9, the predicted average for Algeria is 4 percent, similar to the actual value; it is 8 percent for Morocco

\footnotetext{
${ }^{17}$ The World Investment Report constructs the FDI stocks for Algeria and Morocco by accumulating flows since 1971. For Tunisia, estimates of the FDI stocks are available starting in 1990, and the stocks for 1980 and 1985 are constructed by subtracting flows. If the FDI stock for Morocco was constructed by subtracting flows from the recently published 2002 FDI stock of 31 percent of GDP (not available at the time of the analysis), it would be higher, of the order of 20 percent of GDP in 1990. Yet, the FDI stock-to-GDP ratio of Tunisia would still be significantly higher than those of Morocco and Algeria.
} 
against an actual value of 9 percent; and the predicted average for Tunisia is 79 percent against an actual value of 77 percent.

In Tunisia and Morocco, country-specific factors (captured by country dummies in the regression) contribute to explaining the level of the FDI stock-to-GDP ratio. The predicted FDI stock-to-GDP ratio would be much smaller if the fixed effects for these countries did not differ from the average for all sample countries (see column 3 of Table 9). ${ }^{18}$ Possible candidates for Tunisia- and Morocco-specific factors include the endowment in natural resources and the former colonial link to France. For Algeria, the fixed effect does not play a predominant role. Excluding fixed effects, Morocco's FDI stock would only be 4 percent of GDP in 1999, and is hindered by low education and to a lesser extent low domestic growth and low openness (relative to the average for the three countries). Tunisia's FDI stock on the other hand would be 15 percent of GDP in 1999, higher than in Morocco due to a higher initial stock of FDI, stronger domestic growth, a higher education level, and relatively more openness.

Looking at predicted versus actual growth in the FDI stock-to-GDP ratio, Algeria and Tunisia have not fully benefited from the FDI increases that were warranted by world trends and the improvement in their fundamentals, particularly in the 1990s (see Table 10). The model predicted a strong growth of the FDI stock-to-GDP ratio for Tunisia in the 1995-99, on account of an upward world trend in FDI, strong past growth in Tunisia's stock of FDI, an increase in the education level, and an increase in expected domestic growth. Yet, the FDI stock-to-GDP ratio actually decreased during this period. In Algeria, the FDI stock-to-GDP ratio stagnated and actually declined in 1995-99, despite the upward world trend in FDI and improvements in the education level. On the other hand, Morocco's FDI stock-to-GDP ratio increased strongly, at a rate similar to that predicted by the model. In the case of Algeria, the deterioration of political stability and internal security in the 1990s may have contributed to the decline in the FDI stock-to-GDP ratio. Another possible explanation why Algeria and Tunisia underperformed in the 1990s relative to the behavior of fundamentals may be that the country fixed effects are in fact time varying and may have declined in these countries, as resource-related FDI (oil and gas) declined. Finally, the emergence, for European investors, of new markets in Eastern Europe and the former Soviet Union, and the large privatizations that took place in these countries may have diverted FDI from North Africa toward Eastern Europe. In this context, the creation of a regional market between the Maghreb countries could make these countries more attractive to potential foreign investors.

\section{FDI benefits of a regional trade agreement}

Table 11 reports for each country estimates of the FDI benefits that would result from the creation of a regional market. The simulation uses estimated elasticities from the competitive

\footnotetext{
${ }^{18}$ The predicted ratio would be even lower if we corrected for the fixed effect in the lagged value of the FDI stock-to-GDP ratio, one determinant of the current ratio.
} 
regional model (column 3 of Table 5) and is based on 1999 data. The increase in market size resulting from a regional trade agreement would lead to a simulated increase in each country's FDI stock varying from 62 percent in Algeria to 85 percent in Morocco and 165 percent in Tunisia. In the case of Morocco, securing such FDI gains would benefit from further improvement in the education level of the population.

The magnitude of the simulated FDI gains appears quite large and needs to be interpreted with caution. First, the estimated elasticities may not be best suited to project the effect of a RTA creation, as most of the time-variation in the regional market size variable used in the regressions resulted from the growth of RTA partners rather than change in RTA composition. Second, the FDI model, although useful to estimate correlations on a broad sample of observations, may not be adequate to forecast FDI for individual countries. Other variables, such as relative wage costs, a better proxy for infrastructure, and other aspects of the liberalization would help refine projections. Third, the education level in Morocco had to be estimated based on partial data. However, this exercise illustrates the need for the RTA countries to align domestic business conditions with the best available in the region in order to secure their share of the FDI benefits. In that sense, the creation of a regional market may stimulate virtuous competition between the partner countries.

\section{Conclusion}

This paper has examined whether the market size of a RTA influences the FDI received by participating countries. In addition to traditional determinants of FDI, the FDI model included a measure of RTA market size (for countries belonging to RTAs). The estimations were carried out on a sample of 71 developing countries over the period 1980-99 and yielded a significantly positive effect of RTA market size on FDI. However, domestic population size also appeared to matter, possibly reflecting a labor supply effect rather than a market size effect. The estimations revealed that countries within the same RTA may not benefit to the same extent as those from a different RTA. Countries with relatively higher education and financial stability tend to attract a larger share of the FDI at the expense of other RTA members. The simulation of the FDI effects of the creation of a regional market between Algeria, Morocco, and Tunisia illustrates this risk, and points to the need for Morocco to continue improving education levels. More generally, the creation of an RTA may stimulate virtuous competition between the participating countries, forcing them to improve their investment environment to the best available in the region. Finally, the paper found some evidence of FDI diversion between RTA countries and countries which do not belong to an RTA.

From a policy point of view, this paper does not provide enough evidence to conclude that RTAs are necessarily desirable. As mentioned in the introduction, RTAs may induce costs, due for example to trade diversion. However, the fact that the creation of a RTA, by enlarging the market size of individual countries, tends to stimulate the inflow of FDI is an important benefit which, by its dynamic nature, may well outweigh the static costs of trade 
diversion. A policy advice that the paper allows to make is that if an RTA is to be created, each member country should strive to bring the quality of its business environment to the best available in the region in order to share in the FDI benefits. 
Table 1. Ratio of Average Stock of FDI to GDP - Comparison RTA Versus Non-RTA

\begin{tabular}{lcccc}
\hline & Non-RTA & RTA & Number obs. & $\begin{array}{c}\text { Number RTA } \\
\text { countries }\end{array}$ \\
\hline \multirow{2}{*}{1980} & 0.15 & 0.11 & 96 & 62 \\
1985 & $(0.03)$ & $(0.02)$ & & 64 \\
& 0.16 & 0.14 & 99 & 67 \\
1990 & $(0.03)$ & $(0.02)$ & & \\
& 0.14 & 0.18 & 109 & 70 \\
1995 & $(0.04)$ & $(0.03)$ & & 71 \\
& 0.16 & 0.23 & 117 & \\
1999 & $(0.03)$ & $(0.03)$ & & 126 \\
$1980 \mathrm{~s}$ & 0.24 & 0.30 & 117 & 208 \\
$1990 \mathrm{~s}$ & $(0.04)$ & $(0.03)$ & & \\
& 0.15 & 0.12 & 195 & 334 \\
All years & $(0.02)$ & $(0.02)$ & & \\
& 0.18 & 0.24 & 343 & \\
\hline Note: Stan & $(0.02)$ & $(0.02)$ & 538 & \\
\end{tabular}

Note: Standard errors in parentheses.

Table 2. Ratio of Average FDI Inflow to GDP-

Comparison RTA versus non-RTA

\begin{tabular}{lllcc}
\hline Non-RTA & RTA & $\begin{array}{c}\text { Number of } \\
\text { observations }\end{array}$ & $\begin{array}{c}\text { Number RTA } \\
\text { countries }\end{array}$ \\
\hline $1980-85$ & 0.008 & 0.010 & 96 & 62 \\
$1985-90$ & $(0.003)$ & $(0.002)$ & & 64 \\
$1990-95$ & 0.015 & 0.014 & 99 & 67 \\
$1995-99$ & $(0.005)$ & $(0.004)$ & & 709 \\
$1980 \mathrm{~s}$ & 0.018 & 0.015 & 109 & 126 \\
& $(0.004)$ & $(0.003)$ & & \\
$1990 \mathrm{~s}$ & 0.028 & 0.033 & 117 & \\
& $(0.005)$ & $(0.004)$ & & \\
All years & 0.012 & 0.012 & 195 & 263 \\
& $(0.003)$ & $(0.002)$ & & \\
\hline
\end{tabular}

Note: Standard errors in parentheses. 
Table 3. Ratio of Average Stock of FDI to GDPRTA Countries by Geographical Area

\begin{tabular}{lcccc}
\hline & ASEAN & GCC & $\begin{array}{c}\text { Sub-Saharan } \\
\text { Africa RTA }\end{array}$ & $\begin{array}{c}\text { Western } \\
\text { Hemisphere RTA }\end{array}$ \\
\hline \multirow{2}{*}{1980} & 0.23 & 0.05 & 0.09 & 0.13 \\
1985 & $(0.07)$ & $(0.08)$ & $(0.03)$ & $(0.04)$ \\
& 0.31 & 0.09 & 0.11 & 0.15 \\
1990 & $(0.08)$ & $(0.08)$ & $(0.03)$ & $(0.04)$ \\
1995 & 0.37 & 0.10 & 0.17 & 0.18 \\
& $(0.11)$ & $(0.11)$ & $(0.04)$ & $(0.05)$ \\
1999 & 0.41 & 0.16 & 0.19 & 0.25 \\
\multirow{2}{*}{ All years } & $(0.10)$ & $(0.11)$ & $(0.04)$ & $(0.05)$ \\
& 0.44 & 0.25 & 0.24 & 0.39 \\
Number of countries 1980 & $(0.11)$ & $(0.13)$ & $(0.05)$ & $(0.06)$ \\
Number of countries 1999 & 0.36 & 0.13 & 0.16 & 0.22 \\
& $(0.04)$ & $(0.05)$ & $(0.02)$ & $(0.02)$ \\
\hline
\end{tabular}

Note: Standard errors in parentheses.

Table 4. Ratio of Average FDI Inflow to GDPRTA Countries by Geographical Area

\begin{tabular}{lllcc}
\hline & ASEAN & GCC & $\begin{array}{c}\text { Sub-Saharan } \\
\text { Africa RTA }\end{array}$ & $\begin{array}{c}\text { Western } \\
\text { Hemisphere RTA }\end{array}$ \\
\hline \multirow{2}{*}{$1980-85$} & 0.034 & 0.011 & 0.010 & 0.005 \\
$1985-90$ & $(0.008)$ & $(0.009)$ & $(0.003)$ & $(0.004)$ \\
& 0.048 & 0.005 & 0.013 & 0.010 \\
$1990-95$ & $(0.014)$ & $(0.014)$ & $(0.005)$ & $(0.007)$ \\
$1995-99$ & 0.051 & 0.020 & 0.008 & 0.019 \\
& $(0.009)$ & $(0.009)$ & $(0.003)$ & $(0.004)$ \\
All years & 0.046 & 0.031 & 0.021 & 0.048 \\
& $(0.012)$ & $(0.013)$ & $(0.005)$ & $(0.006)$ \\
& 0.045 & 0.017 & 0.013 & 0.021 \\
& $(0.006)$ & $(0.006)$ & $(0.002)$ & $(0.003)$ \\
\hline
\end{tabular}

Note: Standard errors in parentheses. 
Table 5: Autoregressive model of the level of FDI stock ${ }^{1,2}$

(Feasible generalized least squares with correction for panel-heteroskedasticity ${ }^{3}$ ) Dependent variable: $\log \left(\mathrm{FDI}_{+1}\right)$

\begin{tabular}{|c|c|c|c|}
\hline & \multirow[t]{2}{*}{ Domestic model } & \multicolumn{2}{|c|}{ Regional model } \\
\hline & & Market size & Competitive \\
\hline year90 & $\begin{array}{c}0.33 \\
(12.02)^{* *}\end{array}$ & $\begin{array}{c}0.30 \\
(9.90)^{* *}\end{array}$ & $\begin{array}{c}0.27 \\
(5.20)^{* *}\end{array}$ \\
\hline year95 & $\begin{array}{c}0.52 \\
(11.94)^{* *}\end{array}$ & $\begin{array}{c}0.52 \\
(12.09)^{* *}\end{array}$ & $\begin{array}{c}0.59 \\
(7.85)^{* *}\end{array}$ \\
\hline year99 & $\begin{array}{c}0.62 \\
(9.84)^{* *}\end{array}$ & $\begin{array}{c}0.55 \\
(9.31)^{* *}\end{array}$ & $\begin{array}{c}0.72 \\
(6.05)^{* *}\end{array}$ \\
\hline $\log (\mathrm{FDI})$ & $\begin{array}{c}0.48 \\
(13.90)^{* *}\end{array}$ & $\begin{array}{c}0.44 \\
(14.87)^{* *}\end{array}$ & $\begin{array}{c}0.43 \\
(12.85)^{* *}\end{array}$ \\
\hline $\log (\mathrm{Y})$ & $\begin{array}{l}-0.07 \\
(0.69)\end{array}$ & $\begin{array}{l}-0.22 \\
(1.81)\end{array}$ & $\begin{array}{l}-0.21 \\
(1.50)\end{array}$ \\
\hline $\log ($ REGY) & & $\begin{array}{c}0.40 \\
(3.56)^{* *}\end{array}$ & $\begin{array}{c}0.60 \\
(5.63)^{* *}\end{array}$ \\
\hline $\mathrm{g}_{\mathrm{Y}}$ & $\begin{array}{c}4.40 \\
(9.01)^{* *}\end{array}$ & $\begin{array}{c}4.20 \\
(7.34)^{* *}\end{array}$ & $\begin{array}{c}3.02 \\
(3.25)^{* *}\end{array}$ \\
\hline $\mathrm{REGg}_{\mathrm{Y}}$ & & & $\begin{array}{c}0.47 \\
(0.36)\end{array}$ \\
\hline $\log ($ educ) & $\begin{array}{c}0.71 \\
(7.88)^{* *}\end{array}$ & $\begin{array}{c}0.74 \\
(10.37)^{* *}\end{array}$ & $\begin{array}{c}0.34 \\
(2.14)^{*}\end{array}$ \\
\hline $\log$ (GAPeduc) & & & $\begin{array}{c}2.02 \\
(6.00)^{* *}\end{array}$ \\
\hline $\log$ (stabfin) & $\begin{array}{c}0.35 \\
(5.17)^{* *}\end{array}$ & $\begin{array}{c}0.38 \\
(5.73)^{* *}\end{array}$ & $\begin{array}{c}0.04 \\
(0.26)\end{array}$ \\
\hline $\log$ (GAPstabfin) & & & $\begin{array}{c}0.71 \\
(3.74)^{* *}\end{array}$ \\
\hline $\log (\mathrm{tv})$ & $\begin{array}{c}0.01 \\
(0.49)\end{array}$ & $\begin{array}{l}-0.03 \\
(1.19)\end{array}$ & $\begin{array}{l}-0.06 \\
(1.27)\end{array}$ \\
\hline $\log$ (GAPtv) & & & $\begin{array}{c}0.05 \\
(1.05)\end{array}$ \\
\hline $\operatorname{res}(\mathrm{X} / \mathrm{Y})$ & $\begin{array}{c}0.25 \\
(2.76)^{* *} \\
\end{array}$ & $\begin{array}{c}0.16 \\
(1.73) \\
\end{array}$ & $\begin{array}{c}0.16 \\
(1.93) \\
\end{array}$ \\
\hline Observations & 259 & 260 & 268 \\
\hline Number of countries & 71 & 71 & 71 \\
\hline
\end{tabular}


Table 6. Regional Model: Estimation in First Difference and Instrumentation ${ }^{1,2,3}$

Dependent variable: $\operatorname{dlog}\left(\mathrm{FDI}_{+1}\right)$

\begin{tabular}{|c|c|c|}
\hline & \multicolumn{2}{|c|}{ Competitive regional model } \\
\hline & First difference & 2SLS \\
\hline \multirow[t]{2}{*}{ constant } & 0.33 & 0.27 \\
\hline & $(4.18)^{* *}$ & $(2.55)^{*}$ \\
\hline \multirow[t]{2}{*}{ year95-year90 } & 0.06 & \\
\hline & $(0.97)$ & \\
\hline \multirow[t]{2}{*}{ year99-year95 } & -0.04 & -0.07 \\
\hline & $(0.76)$ & $(1.37)$ \\
\hline \multirow[t]{2}{*}{ dlog (FDI) } & 0.17 & 0.27 \\
\hline & $(5.33)^{* *}$ & $(3.93)^{* *}$ \\
\hline \multirow[t]{2}{*}{$\operatorname{dlog}(\mathrm{Y})$} & 0.04 & -0.42 \\
\hline & $(0.13)$ & $(0.86)$ \\
\hline \multirow[t]{2}{*}{ dlog (REGY) } & 0.51 & 0.49 \\
\hline & $(1.99)^{*}$ & $(1.63)$ \\
\hline \multirow[t]{2}{*}{$\mathrm{d}\left(\mathrm{g}_{\mathrm{Y}}\right)$} & 1.58 & -3.68 \\
\hline & $(1.03)$ & $(1.09)$ \\
\hline \multirow[t]{2}{*}{$\mathrm{d}\left(\mathrm{REGg}_{\mathrm{Y}}\right)$} & -2.73 & 6.89 \\
\hline & $(1.34)$ & $(1.56)$ \\
\hline \multirow[t]{2}{*}{ dlog (educ) } & -0.41 & 0.62 \\
\hline & $(1.05)$ & $(1.90)$ \\
\hline \multirow[t]{2}{*}{ dlog (GAPeduc) } & 1.13 & -0.63 \\
\hline & $(1.94)$ & $(0.63)$ \\
\hline \multirow[t]{2}{*}{ dlog (stabfin) } & 0.13 & 0.11 \\
\hline & $(0.71)$ & $(0.57)$ \\
\hline \multirow[t]{2}{*}{ dlog (GAPstabfin) } & 0.45 & 0.60 \\
\hline & $(1.34)$ & $(1.46)$ \\
\hline \multirow[t]{2}{*}{$\operatorname{dlog}(\mathrm{tv})$} & 0.03 & 0.02 \\
\hline & $(0.42)$ & $(0.19)$ \\
\hline \multirow[t]{2}{*}{ dlog (GAPtv) } & -0.02 & -0.10 \\
\hline & $(0.27)$ & $(0.83)$ \\
\hline \multirow[t]{2}{*}{ dres $(\mathrm{X} / \mathrm{Y})$} & 0.33 & -0.01 \\
\hline & $(1.81)$ & $(0.04)$ \\
\hline Observations & 183 & 118 \\
\hline Adjusted R-squared & 0.21 & 0.11 \\
\hline
\end{tabular}

$1 /$ Absolute value of t-statistics in parentheses. * significant at 5 percent level;

** significant at 1 percent level.

2/ The model is estimated by OLS with heteroskedasticity-robust standard errors in the first column and by two stage least squares with heteroskedasticity-robust standard errors in the second column. In the 2SLS procedure, the variables dlog $(\mathrm{FDI}), \mathrm{dlog}(\mathrm{Y})$, and $\mathrm{d}\left(\mathrm{g}_{\mathrm{Y}}\right)$ are instrumented by $\log \left(\mathrm{FDI}_{-1}\right), \mathrm{d} \log \left(\mathrm{Y}_{-1}\right), \mathrm{d}\left(\mathrm{g}_{\mathrm{Y}-1}\right), \mathrm{d} \log \left(\right.$ educ $\left._{-1}\right), \mathrm{dlog}\left(\right.$ GAPeduc $\left._{-1}\right), \mathrm{dlog}\left(\right.$ stabfin $\left._{-1}\right)$, dlog $\left(\right.$ GAPstabfin $\left._{-1}\right)$, $\operatorname{dlog}\left(\mathrm{tv}_{-1}\right)$, dlog $\left(\mathrm{GAPtv}_{-1}\right)$, dres $\left(\mathrm{X} / \mathrm{Y}_{-1}\right)$, and the exogenous variables of the model following the Arellano-Bond (1991) method for dynamic panel models.

3/ Outliers have been eliminated based on the DFITS and COVRATIO tests. 
Table 7. Regional Model: Sensitivity Tests ${ }^{1,2}$

(Feasible generalised least squares with correction for panel-heteroskedasticity ${ }^{3}$ )

Dependent variable: $\log \left(\mathrm{FDI}_{+1}\right)$

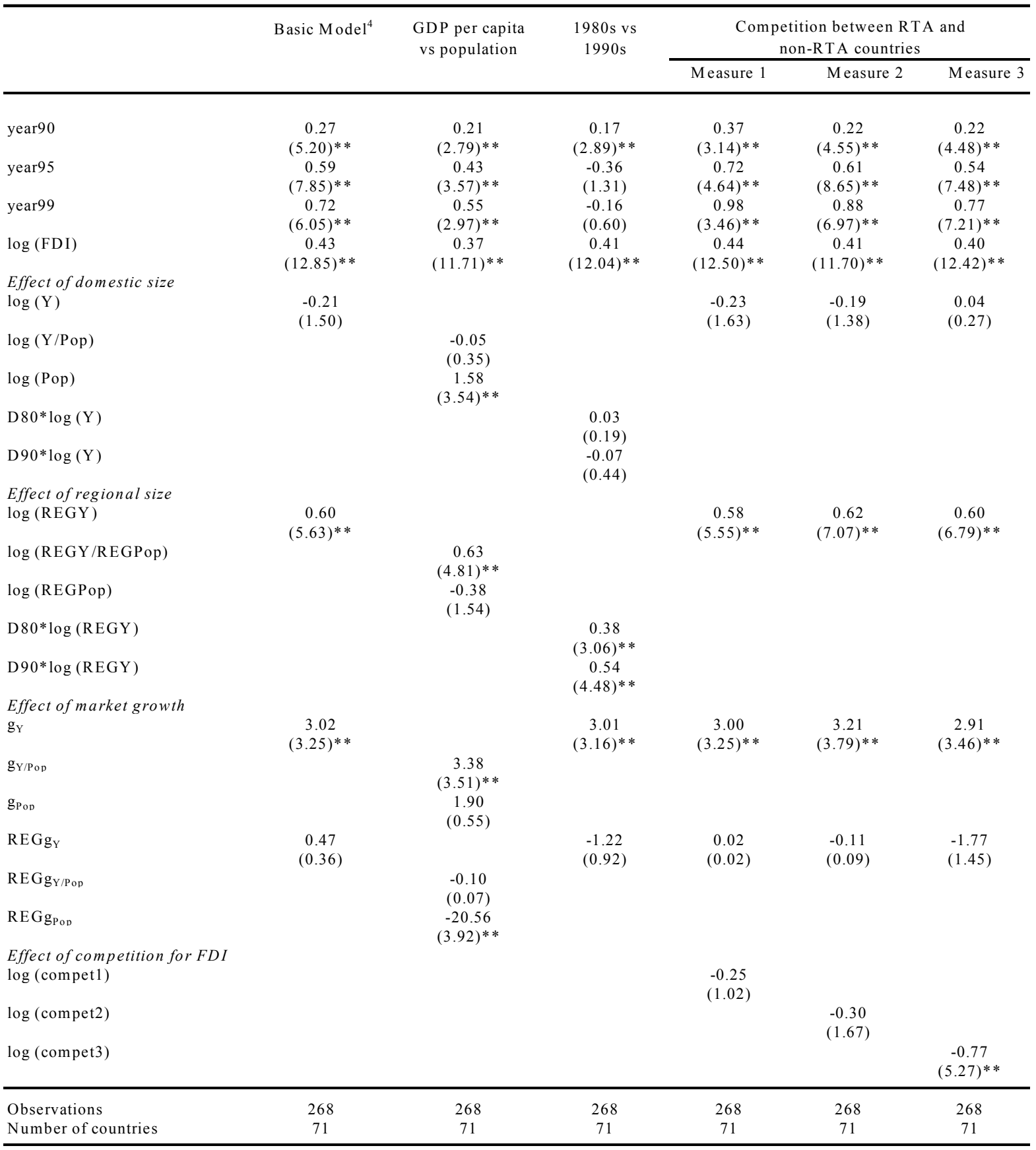

$1 /$ Absolute value of t-statistics in parentheses. * significant at 5 percent level; $* *$ significant at 1 percent level.

2/ The models include country fixed effects, as well as $\log$ (educ), $\log$ (stabfin), log (tv), $\log$ (GAPeduc),

$\log$ (GAPstabfin), $\log$ (GAPtv), and res (X/Y).

3/ Outliers have been eliminated based on the DFITS and COVRATIO tests.

4/ The basic model is the model in column 3 of Table 5 . 
Table 8. FDI in Percent of GDP for Maghreb Countries

\begin{tabular}{|c|c|c|c|c|c|c|}
\hline & \multicolumn{3}{|c|}{ Ratio of stock of FDI to GDP } & \multicolumn{3}{|c|}{ Ratio of FDI inflow to GDP 1/ } \\
\hline & Algeria & Morocco & Tunisia & Algeria & Morocco & Tunisia \\
\hline 1980 & 0.05 & 0.01 & 0.83 & -0.000 & 0.004 & 0.027 \\
\hline 1985 & 0.04 & 0.03 & 0.79 & 0.000 & 0.005 & 0.008 \\
\hline 1990 & 0.04 & 0.04 & 0.71 & 0.000 & 0.015 & 0.068 \\
\hline 1995 & 0.04 & 0.11 & 0.87 & 0.000 & 0.021 & 0.003 \\
\hline 1999 & 0.04 & 0.17 & 0.70 & & & \\
\hline 1980 s & 0.04 & 0.03 & 0.78 & 0.000 & 0.004 & 0.018 \\
\hline $1990 \mathrm{~s}$ & 0.04 & 0.11 & 0.76 & 0.000 & 0.018 & 0.036 \\
\hline All years & 0.04 & 0.07 & 0.78 & 0.000 & 0.011 & 0.027 \\
\hline
\end{tabular}

1/ Annual average over the periods 1980-85, 1985-90, 1990-95, and 1995-99. 
Table 9. Actual and Predicted FDI Stock-to-GDP Ratio for Maghreb Countries 1/

\begin{tabular}{|c|c|c|c|}
\hline & Actual FDI/Y & Predicted FDI/Y & $\begin{array}{l}\text { Predicted FDI/Y } \\
\text { without fixed effect }\end{array}$ \\
\hline \multicolumn{4}{|l|}{ Algeria } \\
\hline 1985 & 0.04 & 0.02 & 0.02 \\
\hline 1990 & 0.04 & 0.04 & 0.02 \\
\hline 1995 & 0.04 & 0.05 & 0.03 \\
\hline 1999 & 0.04 & 0.05 & 0.03 \\
\hline Average & 0.04 & 0.04 & 0.03 \\
\hline \multicolumn{4}{|l|}{ Morocco } \\
\hline 1985 & 0.03 & 0.03 & 0.01 \\
\hline 1990 & 0.04 & 0.05 & 0.01 \\
\hline 1995 & 0.11 & 0.10 & 0.03 \\
\hline 1999 & 0.17 & 0.15 & 0.04 \\
\hline Average & 0.09 & 0.08 & 0.02 \\
\hline \multicolumn{4}{|l|}{ Tunisia } \\
\hline 1985 & 0.79 & 0.56 & 0.08 \\
\hline 1990 & 0.71 & 0.68 & 0.09 \\
\hline 1995 & 0.87 & 0.86 & 0.12 \\
\hline 1999 & 0.70 & 1.06 & 0.15 \\
\hline Average & 0.77 & 0.79 & 0.11 \\
\hline
\end{tabular}

1/ The predictions are based on the estimation of the competitive regional model (column 3 in Table 5). 
Table 10. Actual and Predicted Average Annual Growth of the FDI Stock-to-GDP Ratio (In percent) $1 /$

\begin{tabular}{lcc}
\hline & Actual FDI/Y growth & Predicted FDI/Y growth \\
\hline Algeria & & \\
& & \\
$1985-90$ & -0.24 & 7.41 \\
$1990-95$ & 0.39 & 6.14 \\
$1995-99$ & -2.91 & 1.04 \\
& & \\
Morocco & & \\
& & 11.31 \\
$1985-90$ & 9.64 & 16.50 \\
$1990-95$ & 21.75 & 10.39 \\
$1995-99$ & 10.67 & \\
& & \\
Tunisia & & 4.11 \\
& & 4.66 \\
$1985-90$ & -1.89 & 5.42 \\
$1990-95$ & 4.06 & \\
\hline $1995-99$ & -5.21 & \\
\hline
\end{tabular}

$1 /$ The predictions are based on the estimation of the competitive regional model (column 3 in Table 5).

Table 11. Growth in the FDI Stock-to-GDP Ratio Implied by the Creation of a Maghreb Regional Market (In percent) 1/

\begin{tabular}{|c|c|c|c|c|}
\hline & Total effect & Market size effect & $\begin{array}{c}\text { Relative education } \\
\text { effect }\end{array}$ & $\begin{array}{c}\text { Relative financial } \\
\text { stability effect }\end{array}$ \\
\hline Algeria & 110 & 62 & 35 & -4 \\
\hline Morocco & 7 & 85 & -44 & 4 \\
\hline Tunisia & 215 & 165 & 19 & 0 \\
\hline
\end{tabular}


Figure 1: Partial Correlation FDI—Domestic Market Size

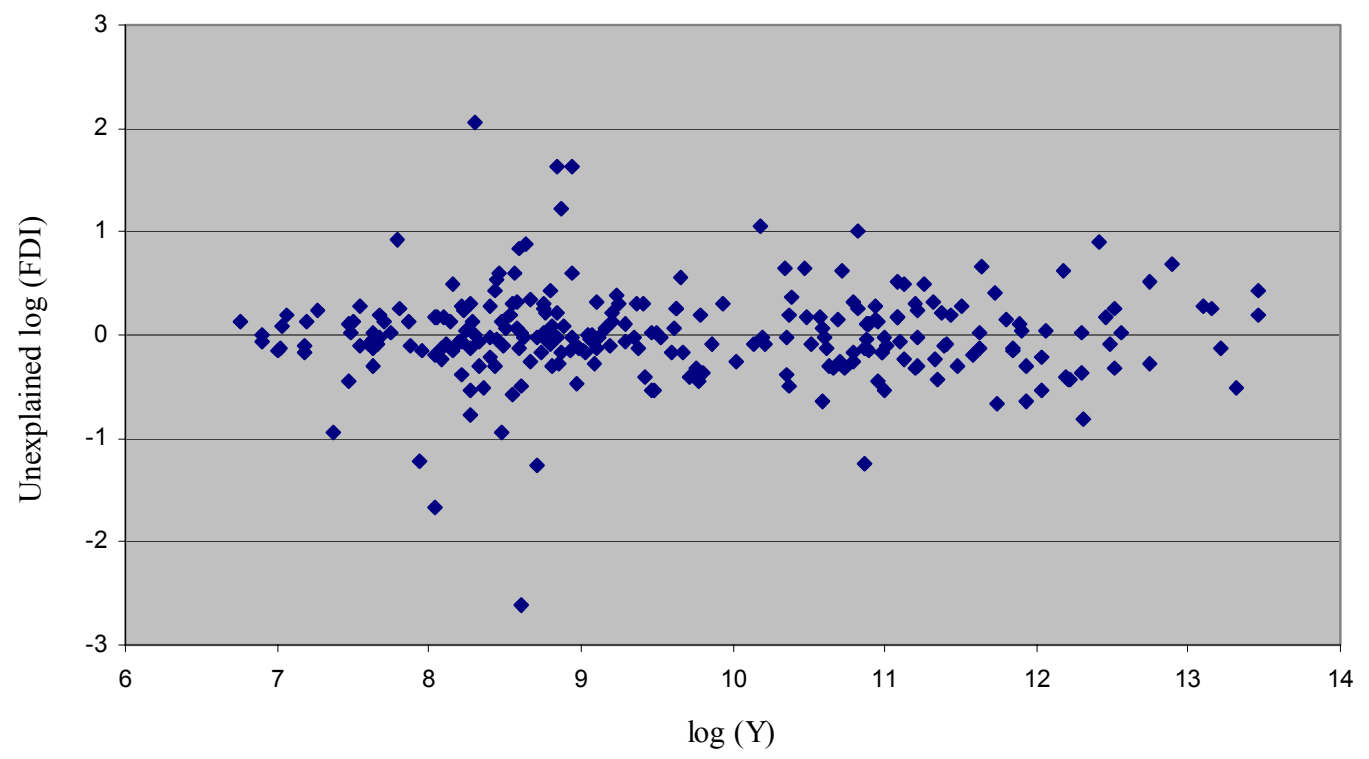

Figure 2: Partial Correlation FDI—Regional Market Size

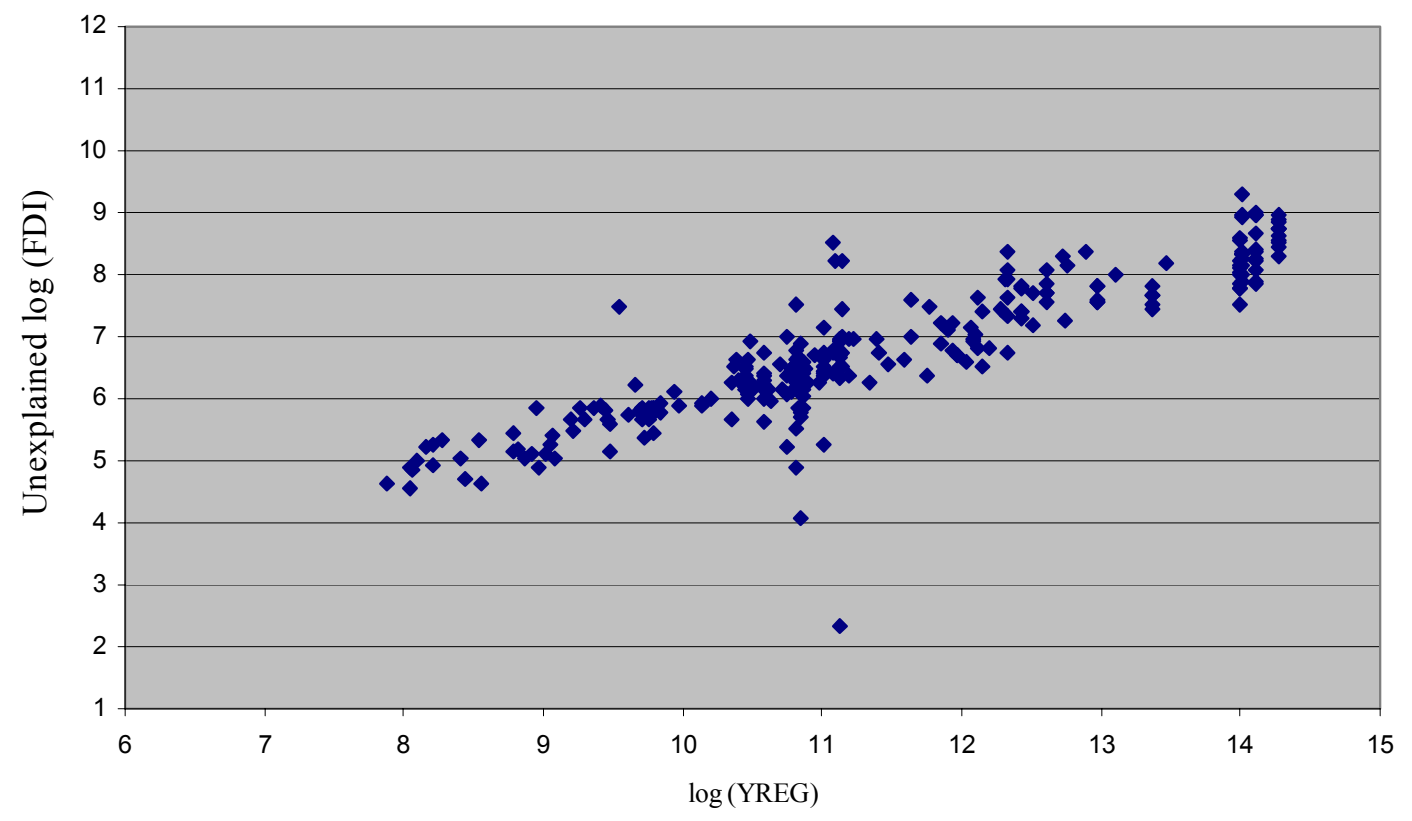




\section{List of South-South Regional Trade Agreements ${ }^{19}$}

\section{Latin America}

\section{Central American Common Market (CACM)}

Costa Rica, El Salvador, Guatemala, Honduras, Nicaragua and Panama. ${ }^{20}$

The Andean Pact

Bolivia, Colombia, Ecuador, Peru, and Venezuela.

Latin American Integration Association (LAIA)

Argentina, Bolivia, Brazil, Chile, Colombia, Ecuador, Mexico, Paraguay, Peru, Uruguay and Venezuela.

\section{Caribbean Community and Common Market (CARICOM)}

Antigua and Barbuda, The Bahamas, Barbados, Belize, Dominica, Grenada, Guyana, Jamaica, Montserrat, St. Kitts-Nevis, St. Lucia, St. Vincent and the Grenadines, and Suriname and Trinidad and Tobago.

Common Market of the South (MERCOSUR) - since 1991

Argentina, Bolivia (since 1996), Brazil, Chile (since 1996), Paraguay and Uruguay.

Group of Three (G3) - since 1994

Colombia, Mexico, and Venezuela.

\section{Asia}

Association of South East Asian Nations (ASEAN)

Brunei (since 1984), Cambodia (since 1999), Indonesia, Lao People's Democratic Republic (since 1997), Myanmar (since 1997), Malaysia, Philippines, Singapore, Thailand, and Vietnam (since 1995).

\section{Middle East and North Africa}

The Gulf Cooperation Council (GCC) - since 1981

Bahrain, Kuwait, Oman, Qatar, Saudi Arabia, and the United Arab Emirates.

\footnotetext{
19 The information on RTAs is taken from the World Bank website on Trade. Unless mentioned otherwise, the RTAs have been in effect during the entire period covered in this paper (1980-99).

${ }^{20}$ Panama is not formally a member but has limited preferential agreements with individual members of the CACM.
} 


\section{Sub-Saharan Africa}

Economic Community of Western African States (ECOWAS)

Benin, Burkina Faso, Cape Verde, Côte d'Ivoire, The Gambia, Ghana, Guinea, Guinea-Bissau, Liberia, Mali, Niger, Nigeria, Senegal, Sierra Leone, and Togo.

Union Economique et Monétaire Ouest-Africaine (UEMOA)

Benin, Burkina Faso, Côte d'Ivoire, Guinea-Bissau (since 1997), Mali, Niger, Senegal, and Togo.

Communauté Economique et Monétaire d'Afrique Centrale (CEMAC)

Cameroon, Central African Republic, Chad, Republic of Congo, Equatorial Guinea (since 1985), and Gabon.

Common Market for Eastern and Southern Africa (COMESA) - since 1981

Angola, Burundi, Comoros, Democratic Republic of Congo, Djibouti, Egypt, Eritrea, Ethiopia, Kenya, Madagascar, Malawi, Mauritius, Namibia, Rwanda, Sudan, Swaziland, Uganda, Tanzania, Zambia, and Zimbabwe.

\section{Southern African Development Community (SADC)}

Angola, Botswana, Democratic Republic of Congo, Lesotho, Malawi, Mauritius (since 1995), Mozambique, Namibia, Seychelles, South Africa (since 1994), Tanzania, Zambia, Zimbabwe, and Swaziland.

Southern African Customs Union (SACU)

Botswana, Lesotho, Namibia, South Africa and Swaziland.

Cross Border Initiative (CBI) - since 1990

Burundi, Comoros, Kenya, Madagascar, Malawi, Mauritius, Namibia, Rwanda, Seychelles, Swaziland, Tanzania, Uganda, Zambia, and Zimbabwe. 


\section{List of Sample Economies ${ }^{1}$}

Asia
Bangladesh
China
Hong Kong SAR
India
Indonesia*
Korea
Malaysia*
Myanmar
Pakistan
Papua New Guinea
Philippines*
Singapore*
Sri Lanka
Thailand*
Middle East and North Africa

\section{Algeria}

Bahrain*

Cyprus

Egypt

Iran, I.R. of

Israel

Jordan

Kuwait*

Morocco

Syrian Arab Rep.

Tunisia

Turkey

Sub-Saharan Africa

Botswana*

Cameroon*

Congo*

Ghana*

Kenya*

Liberia*

Malawi*

Mali*

Mozambique*

Niger*

Senegal*

\author{
Sierra Leone* \\ South Africa* \\ Sudan* \\ Tanzania* \\ Togo* \\ Uganda* \\ Zaïre \\ Zambia* \\ Zimbabwe* \\ Europe \\ Bulgaria \\ Hungary \\ Poland \\ Romania
}

\section{Western Hemisphere}

Argentina*
Bolivia*
Brazil*
Chile*
Colombia*
Costa Rica*
Dominican Republic
Ecuador*
El Salvador*
Guatemala*
Haiti
Honduras*
Jamaica*
Mexico*
Nicaragua*
Panama*2
Paraguay*
Peru*
Trinidad and Tobago*
Uruguay*
Venezuela*

Argentina*

Bolivia*

Brazil*

Chile *

Colombia*

Costa Rica

Ecuador*

El Salvador*

Guatemala*

Haiti

Honduras*

Jamaica

Panama* ${ }^{2}$

Paraguay*

Peru*

Uruguay*

Venezuela*

$1 / *$ denotes countries that belonged to a South-South RTA in 1995.

2/ Panama is not formally a member but has limited preferential agreements with individual members of the CACM. 


\section{Summary Statistics and Correlation Matrix}

Table A1. Summary Statistics of Selected Variables

\begin{tabular}{lcccc}
\hline Variable & Mean & Std. Dev. & Min & Max \\
\hline & & & & 292770 \\
FDI+1 & 11488 & 29937 & 1 & 133022 \\
FDI & 6845 & 17387 & 1 & 703960 \\
Y & 56143 & 107811 & 368 & 1595214 \\
REGY & 304638 & 478799 & 2650 & 0.12 \\
g $_{\text { }}$ & 0.03 & 0.04 & -0.10 & 0.12 \\
REGg & 0.03 & 0.03 & -0.10 & 10.6 \\
educ & 4.7 & 2.2 & 0.5 & 48.0 \\
stabfin & 27.1 & 8.3 & 6.8 & 439.0 \\
tv & 107.5 & 111.5 & 0.0 & 2.5 \\
res $(X / Y)$ & 0.5 & 0.4 & 0.0 & \\
\hline Note: The & & & \\
\hline
\end{tabular}

Note: The summary statistics are calculated for the 268 sample observations of the competitive regional model (see Table 5). FDI denotes the stock of FDI (in millions of 1995 U.S. dollars), Y is real GDP (in millions of 1995 U.S. dollars), REGY is the regional market size (in millions of 1995 U.S. dollars), gY denotes real GDP growth, REGgY denotes the average real growth rate in RTA partner countries (including the own country), educ denotes the average years of education of people over age 15, stabfin is the financial risk index of the Political Risk Services Group, tv is the number of televisions per 1000 people, and $\operatorname{res}(\mathrm{X} / \mathrm{Y})$ is the measure of trade openness.

Table A2. Correlation Matrix Between Selected Variables

\begin{tabular}{|c|c|c|c|c|c|c|c|c|c|c|}
\hline & FDI+1 & FDI & $\mathrm{Y}$ & REGY & $\mathrm{g}_{\mathrm{Y}}$ & $\mathrm{REGg}_{\mathrm{Y}}$ & educ & stabfin & tv & $\operatorname{res}(\mathrm{X} / \mathrm{Y})$ \\
\hline $\mathrm{FDI}+1$ & 1.00 & & & & & & & & & \\
\hline FDI & 0.92 & 1.00 & & & & & & & & \\
\hline $\mathrm{Y}$ & 0.64 & 0.55 & 1.00 & & & & & & & \\
\hline REGY & 0.23 & 0.20 & 0.38 & 1.00 & & & & & & \\
\hline$g_{Y}$ & 0.30 & 0.30 & 0.17 & 0.07 & 1.00 & & & & & \\
\hline $\mathrm{REGg}_{\mathrm{Y}}$ & 0.34 & 0.33 & 0.22 & 0.07 & 0.80 & 1.00 & & & & \\
\hline educ & 0.28 & 0.27 & 0.25 & 0.31 & 0.09 & 0.11 & 1.00 & & & \\
\hline stabfin & 0.40 & 0.42 & 0.23 & 0.16 & 0.38 & 0.31 & 0.51 & 1.00 & & \\
\hline tv & 0.36 & 0.35 & 0.28 & 0.24 & 0.03 & 0.02 & 0.71 & 0.55 & 1.00 & \\
\hline $\operatorname{res}(\mathrm{X} / \mathrm{Y})$ & 0.47 & 0.53 & 0.09 & -0.01 & 0.18 & 0.21 & 0.22 & 0.35 & 0.30 & 1.00 \\
\hline
\end{tabular}

Note: The correlations are calculated for the 268 sample observations of the competitive regional model (see Table 5). FDI denotes the stock of FDI (in millions of 1995 U.S. dollars), Y is real GDP (in millions of 1995 U.S. dollars), REGY is the regional market size (in millions of 1995 U.S. dollars), gY denotes real GDP growth, REGgy denotes the average real growth rate in RTA partner countries (including the own country), educ denotes the average years of education of people over age 15, stabfin is the financial risk index of the Political Risk Services Group, tv is the number of televisions per 1000 people, and res $(\mathrm{X} / \mathrm{Y})$ is the measure of trade openness. 


\section{References}

Arellano, M., and S. Bond, 1991, "Some Tests of Specification for Panel Data: Monte-Carlo Evidence and an Application to Employment Equations," Review of Economic Studies, Vol. 58, pp.277-97.

Baldwin, R.E., and T. Venables,1995, "Regional Economic Integration," in Handbook of International Economics, edited by G. Grossman and K. Rogoff, Vol. 3 (New York: North-Holland).

Barro, R.J., and J.W. Lee, 2000, "International Data on Educational Attainment Updates and Implications," NBER Working Paper No. 7911 (Cambridge, Mass: National Bureau of Economic Research).

Barro, R.J., and X. Sala-i-Martin, 1999, "Determinants of Economic Growth: Implications of the Global Evidence for Chile," Cuadernos de Economia (Chile) 36, No. 107, pp. 443-78.

Blomström, M., S. Globerman, and A. Kokko, 2000, “The Determinants of Host Country Spillovers From Foreign Direct Investment," CEPR Working Paper No 2350.

Blomström, M., and A. Kokko, 1997, "Regional Integration and Foreign Direct Investment”, NBER Working Paper No 6019.

Borenzstein, E., J. De Gregorio, and J.W. Lee, 1995, "How Does Foreign Direct Investment Affect Economic Growth?," NBER Working Paper No 5057.

Caves, R.E. 1996, "Multinational Enterprise and Economic Analysis," Cambridge Surveys of Economic Literature, Cambridge University Press.

Chudnovsky D., A. Lopez, and F. Porta, 1995, "New Foreign Direct Investment in Argentina: Privatization, the Domestic Market, and Regional Integration," in Foreign Direct Investment in Latin America, ed. by M.R. Agosin (Washington: Inter American Development Bank), distributed by John Hopkins University Press, Baltimore.

De la Torre, A., and M. Kelly, 1992, Regional Trade Arrangements, IMF Occasional Paper No. 93 (Washington: International Monetary Fund).

Dunning, J. 1997, "The European Internal Market Programmed and Inbound Foreign Direct Investment," Journal of Common Market Studies, Vol. 35, Issue 2, June, pp.189-223.

Girma, S., 2001, "The Process of European Integration and the Determinants of Entry by Non-EU Multinationals in UK manufacturing”, GEP Research Paper 2001/20, (Nottingham, England: University of Nottingham), September. 
International Monetary Fund, Balance of Payments Statistics Yearbook (Washington: various years).

— Direction of Trade Statistics (Washington: various years).

$\longrightarrow$, World Economic Outlook (Washington: various years).

Lim, E.G., 2001, "Determinants of, and the Relation Between, Foreign Direct Investment and Growth: A Summary of the Recent Literature," IMF Working Paper 01/175 (Washington: International Monetary Fund) November.

Michalet, C.A., 1997, "Strategies of Multinationals and Competition for Foreign Direct Investment: The Opening of Central and Eastern Europe," Foreign Investment Advisory Service Occasional Paper 10 (Washington: The World Bank).

Pain, N., 1997, "Continental Drift: European Integration and the Location of U.K. Foreign Direct Investment," The Manchester School of Economic and Social Studies, Vol. 65, Issue 0, Supplement, pp. 94-117.

— European Direct Investment," (unpublished; London National Institute of Economic and Social Research).

_ 1997, "Regional Economic Integration and Foreign Direct Investment: The Case of German Investment in Europe," National Institute Economic Review, Vol. 0, Issue 160, April, pp. 87-99.

Sevestre P, and A. Trognon, 1996, "Dynamic Linear Models" in The Econometrics of Panel Data: A Handbook of the Theory with Applications, ed. by L. Matyas and P.

Sevestre (Norwell, Mass.: Kluwer Academic Publishers), pp,120-44.

Singh H., and K.W. Jun, 1995, "Some New Evidence on Determinants of Foreign Direct Investment in Developing Countries," World Bank Policy Research Working Paper 1531, (Washington: The World Bank).

Torrisi, C.R., 1985, "The Determinants of Direct Foreign Investment in a Small LDC," Journal of Economic Development, Vol.10 No. 2, pp. 29-45.

UNCTAD, 2000, World Investment Report 2000, (New York: United Nations).

Wheeler, D., and A. Mody, 1992, "International Investment Location Decisions, The Case of U.S. Firms," Journal of International Economics, Vol. 33, Issue 1-2, August, pp. 57-76.

World Bank, 2001, World Development Indicators (Washington). 